\title{
Stephen Burt, production manager
}

During his twenty-year career, Stephen Burt has worked on such projects as The Borgias (2011-13) and Penny Dreadful (2014-16). Although he has a flat in Glasgow, he travels extensively for work, shuttling off to places like Sweden, Germany, Belgium, and Hungary. Here he discusses the rewards and challenges of this mobile lifestyle and reflects on the obstacles his native Scotland faces when competing for foreign productions.

What kinds of jobs are there in the production office?

We're the administrative hub of the production, so the size of the office will vary depending on the size of the production. You'll have your line producer, assistant director, and production manager. You'll have your location manager and his or her assistants. You'll have script coordinators, and a variety of coordinators and administrative assistants for accommodations and travel and office management. We are also responsible for production assistants.

What's a typical workweek like for you?

It depends on the producer and what's customary in different places. A normal production workday in Ireland is twelve hours. But we've been very lucky on Penny Dreadful. We've implemented a ten-hour continuous day and a five-day workweek. We start at eight and end at six. I work with a very unusual group of producers who care about the crew. We're incredibly fortunate. But it is a new thing here, so it has required some adjustments. For instance, the whole crew has to eat 
on the run. There's no time to sit down for a lunch hour, which made it necessary to speak with catering to adjust how they serve meals. We needed something the crew can eat with a fork out of the box while they're working. I think it's been a successful change. People are getting home a few hours earlier than they would on other productions. There's still a bit of light outside. They have some time to enjoy the evening with their families, which is extremely rare in the production world. We're no longer getting home late at night and waking up a few hours later to return to the set. We're also not losing momentum on the set. We're simply working more efficiently.

How so?

It never fails that after lunch on a really long workday everyone loses momentum. Your talent has left the set. Your crew has left the set. It takes time to get everyone revved up and back in tune with the production after we break for lunch. It causes this incredible lag. Shortening the workday has proven to us that when everyone's energy level is high, you can get just as much done in a ten-hour day as you can get done in a twelve-hour day. You're more focused. I've worked eleven-day fortnights and sixty-hour weeks, and I won't do that again. It's just too hard on the crew. There are better ways to get the work done.

Crew members in the United States often tell us that they love the overtime, but the hours are grueling and excessive. They wish the producers were better organized, but if the days were shorter and contained, they would lose the overtime. So nobody speaks out against the system even though they think it's screwy.

I've done American feature film productions. They are grueling, particularly because of the "freaky Friday" phenomenon caused by the SAG-AFTRA agreements. Productions are required to give talent a twelve-hour turnaround between shooting days. So, when you run over your call sheet for the day, it pushes back your start time the following day to allow for that twelve-hour turnaround. You inevitably run over the next day, too, and so on. It's a snowball effect. Then you find yourself on Friday working a nineteen-hour day to complete your shot list for the week. It's simply horrendous. I don't know why anyone does it. It doesn't allow for any quality of life at all. For me, quality of life is more important than money.

Those producers don't understand that the crew is completely exhausted. They don't get the same quality of work in the nineteenth hour as they do in the ninth hour. On our set, we have a built-in safety net already scheduled into our tenhour workday that keeps us from running into issues with talent and turnaround time. If we're scheduled to end at six in the evening but end up running over for whatever reasons, we have a two-hour window in which we can catch up before 
it affects the next day's start time. So if we end the day at eight in the evening, we aren't cutting into our turnaround time. We can give the actors the twelve-hour break stipulated in their contracts and still start on time the next day. But if you're starting with a twelve- or fourteen-hour day and you don't make your schedule, it immediately pushes back the start time the following day. The delays each day then start to pile up until you're working around the clock on Friday to meet that week's schedule.

\section{As production manager, does your workday differ from the crew's?}

I'm usually here an hour before the crew arrives. I start at seven in the morning unless it's a particularly tough day. If I anticipate a rough day, I'll come earlier. And I usually leave an hour later than the crew. So I'm working a twelve-hour day, five days a week. I have my weekends to recover. I know it sounds like you're talking to somebody in a different industry. Penny Dreadful is a compelling case study-it's the most humane job I've ever worked, and that's to the credit of the individual producers.

What are some places where you've recently crewed up?

In the past three years, I've worked in Gothenburg, Sweden; Hamburg, Germany; Ostend, Belgium; Budapest, Hungary; and Dublin, Ireland. In each country, it's imperative for me to liaise with local production managers. They advise me on who's available and who's qualified and what those locations can provide-and, more often, what they can't provide. You simply won't find the same skill levels in other countries as you do in more established filming destinations, like the United Kingdom or Ireland. So my relationship with these local production managers is crucial, but depending on where you're filming, you may end up finding crews from anywhere in Europe to bring to the production.

That's an astounding list-a little daunting, even. Do you find hopscotching around Europe to be challenging?

I think it's fantastic. I love to go to different places. Every country does production work slightly differently. I find it incredibly valuable to learn different systems. It's a great education. It allows me to take the best of what I learn in each location and integrate that knowledge into my own practices. Maybe they're doing something a little better than how I'm accustomed to doing it. I think it makes me much better at my own job.

Of course, it's not without its challenges. There are different union rules. There are different working practices. Standard workdays are different. Are we doing 
ten-hour, eleven-hour, twelve-hour, or fourteen-hour days? Job categories and functions are different. You may have a production coordinator and expect that person to do one thing because that's what he or she did on the last production, but now the production secretary does it and the coordinator does something totally different on this production. A classic example: on European productions, grips work with the camera department; on American productions, grips work with the electrical department.

But this is what keeps it exciting for me. I change jobs every six months. If I had to show up to an office every day for thirty years and work with the same people in the same place, I would go crazy. I find it much more interesting to shuffle around to different places, work with a new group of people, and learn from them.

Professionally, you find it exciting. What about on a personal level? Does it take a particular type of person to do this job?

You can't have a family. You have to be a single man. I don't know anyone who does my job who manages to hold down a relationship. Your lifelong friends also become Facebook friends. I see my mates very rarely. I'm always on the move, in a different place. It doesn't bode well for any sort of commitment. I do keep a flat in Glasgow. I think it's important to have a place to call a home. But it just sits there empty. I think I've been back in Scotland for a total of six weeks in the last three years.

You said "single man." Do you mean a single person? Or is there a gendered dynamic to this line of work?

I think the production office is one of the most inclusive spaces on a film set. There are plenty of women who do this job, and they're fantastic at it. Absolutely. In fact, some of my best mentors have been women. I don't know exact percentages. I'm not even sure they exist. But I'd estimate 50 percent of my contemporaries are women.

Do you find some locations easier than others?

Some locations work like a dream. Some locations are a nightmare. I find crewing up a production in Germany very difficult. They have a very different system. When you're looking for crew in Germany, you'll see people advertise themselves as trained in the "Berlin system" or the "international system" or both. The Berlin system is a unique system of working, with roles that don't appear anywhere else. For example, they have a position that is a cross between a production assistant, an assistant director, and a location manager. Part of the reason the lines are so blurred 
in the system is because it came about after the war when they had no money for the arts or to make films. Everyone had to muck in in order to get the work done. The system involved really compact crews. Different jobs became the responsibility of a single person. I've had to work with this system in other countries outside Germany, including Scotland, and it just doesn't work. You spend so much of your time resolving conflicts. People are always clashing on set: "He shouldn't be doing that. I should be doing that." Or, "He should be doing that. Why isn't he doing that?" Then "Me? It's not my job. Why are you looking at me?" It's a mess.

I love Budapest. It's such a vibrant location-the most fantastic place I've ever worked. I love the weather in the summer. It's affordable, so your per diems give you a nice quality of life while you're there. It offers an incredibly high-caliber crew. It has amazing studios. They have a well-earned reputation as a top-notch production service center right now. Blockbuster film productions and big television series are their bread and butter. What's not to like? They've replaced Prague. I think Romania is on the rise because of its currency rates, but Budapest is simply fantastic.

You raise an interesting point. We hear about locations investing in infrastructure and human capital only to see Hollywood's interest dissipate as the next location emerges. Are these places just the flavor of the month? Does it seem sad to you?

I feel for the crews when that happens, and it does happen. But I don't think it necessarily plays out the way you describe. I think that growth requires a genuine commitment from governments to create a stable incentive system. Look at the notable incentives in the United Kingdom and Ireland. I would include Hungary, too, though its incentive isn't limitless. Hungary's incentive has a cap, so there's always the chance of it running out in a given year. I suspect we'll see that change soon because all it takes for producers to run somewhere else is the perception of a little wobble in the system. You won't lose producers' interest if the incentive program is stable.

But that's taxpayer money going into the producer's pocket. They already have deep pockets. Doesn't that seem like a system that works against the locations?

I don't see it that way. I've worked in enough locations to see the massive spending that productions bring with them. I'm convinced that there's a direct benefit to local economies and local crews. It's absolutely worthwhile. Keep in mind that I don't think there's a need to cut each other's throats in a competition to offer the best incentives, though. It doesn't take a huge incentive to make it worthwhile to producers as long as the location has the necessary physical infrastructure, crew depth, and exchange rate that makes costs like labor and accommodation advantageous. 
You have to look at the bigger picture of what a location offers. A tax incentive is part of a larger package to build upon and sustain existing strengths.

\section{What about a place like Scotland?}

Scotland is a disaster. It makes me incredibly sad. There's no film studio, no dedicated screen agency. The skills base is moving south because the government is embarrassingly apathetic. There's absolutely no support. There's no sense of a genuine interest from the authorities that this is a sector worth saving. When people can't work because there are no jobs, they're going to leave to find work elsewhere. It's certainly a reason why I'm not in Scotland right now.

I can't tell you how many Hollywood producers have visited Scotland because they're interested in our gorgeous mountains and lochs. They love it. Then they ask to see the film studio. When they hear we don't have one, they have no choice but to look somewhere else. We had a chance to host Game of Thrones (2011-ongoing) but it went to Belfast because that location had both a studio facility and local incentives.

Scotland is the only country in Western Europe without a film studio. Local crews have been extremely vocal about it. We actively lobby the government. I've met with the culture minister and other public officials. I've done so much work to convince them of the value of a studio facility. But they pat us on the head. They think they know what's best but refuse to acknowledge what's happening in all these other places. They clearly have no clue.

Let's say Scotland gets the film studio it deserves. Do you think there's space on the global map for one more production hub?

Absolutely. I know from personal experience that you cannot book a stage in London. There's nothing available. We toured the entire United Kingdom looking for a space to film Penny Dreadful. We couldn't find anywhere to shoot it-nowhere! It ended up being quite the embarrassment for the UK. Penny Dreadful was earmarked as the first major production to take advantage of the new television tax incentive in the UK, but when we couldn't find a soundstage, we ended up in Dublin.

Glasgow benefits from the same incentive as London. Yet labor rates are much cheaper because the cost of living is lower. Accommodations, transportation, and other services are far more affordable than you'll find in central London. Glasgow also has an indigenous workforce. It has production and postproduction service companies. It has a variety of urban locations. You can reach the countryside in forty-five minutes. The only thing the city is missing is a studio. If the government doesn't act soon, it's facing a future in which a lot of the creative resources that the city has to offer won't exist anymore, especially the crew. Glasgow's crew is leaving. 
The best people are working, but they're not working in Glasgow. They're working in London, Dublin, Budapest, and Belfast. They're following the work.

\section{What's your message to the Scottish government?}

Build a state-of-the-art studio. And offer a local incentive to complement the UK incentive. The government simply needs to be more proactive. Scotland needs to be seen from the outside as being proactive. You can't take six months to research the implications of a job that only lasts for four months. The government doesn't have the drive and doesn't have the brains. Look at Wales. Look at Northern Ireland. Look at Ireland. It's all around them, and they are oblivious.

\section{How do you describe the value of production to a location?}

I think there are economic arguments to make about the value of film and television production, but for me, there's also a real value to the local crew base that is a critically important factor to consider. You're building a sustainable workforce. You're establishing opportunities for local crew to learn and train among some of the best practitioners in the world. You're establishing opportunities for professional advancement. You're creating opportunities in a context where very few already exist. Scotland makes less than ten high-quality feature films every year. International productions will create more opportunities to learn skills and use equipment that indigenous productions don't offer. This, for me, is a big plus.

You have been a very vocal proponent of increasing government support for Scotland's local crew base. In fact, the country's motion picture workforce is quite active in lobbying for improved conditions.

I'm not as active as I was a few years ago. It's hard to organize when you're away from home for such long stretches of time. But I did help cofound an organization in 2009 called the Association of Film and Television Practitioners Scotland (AFTPS). At the time, I was introduced to Willy Wands through a mutual friend who thought we would have a lot in common. Willy also has an international career that keeps him away from Scotland most of the year. He's also become quite outspoken about the embarrassing lack of support for film and television production. So, the idea for an association of practitioners originated out of that initial meeting with Willy, which was a long moaning session at a local pub.

I just couldn't shake the sense of frustration we discussed that night. It stuck with me for about two weeks after that first meeting. I rang him up to say, "I'm absolutely sick of this feeling. I'm going to call a meeting of the entire industry. 
Something needs to be done. We can't just sit here and watch it die." So, thanks to Willy's reputation and my crazy persistence, we managed to fill the room with more than three hundred freelancers, a vast majority of the industry in Scotland. We decided then that the association would work as a lobby group that would pressure key stakeholders to do a better job for film and television workers in Scotland. We targeted public bodies. We targeted individual members of the Scottish Parliament. We targeted the BBC. We targeted STV.

We had the press on our side. We got a lot of visibility, and they championed our cause. We ended up scheduling meetings with key individuals within those organizations. We saw some real, tangible outcomes from the broadcasters, with some commissioning a few more productions in Scotland. We had less success with the government-just more false promises about what it hoped to do.

I'm less involved today, but the group is still active. It's continued to evolve as a meaningful forum for local crew to raise questions and concerns about job opportunities, working conditions, and so forth. It's also been an active voice in the efforts to secure a studio space. It's a slow process. It's hard to prompt the government to act, but the group is a persistent voice for change.

It's a fascinating example of workers taking it upon themselves to organize in place of more traditional institutions, like the union.

BECTU is a useless organization. Its representative in Scotland is worse than a chocolate teapot. In fact, someone who picks up a weekly wage is not the best advocate for freelancers. He has no concept of precariousness. He has no genuine investment in the fate of local film and television practitioners. He attended that initial meeting of AFTPS. I think the fact that no one knew who he was when he showed up to the meeting speaks for itself. He got a bit of a fright from the amount of anger in the room targeting the union's lack of support. It prompted some tangible change as well. For instance, as a consequence of that meeting, BECTU now offers training schemes in Scotland-seminars on budgets, production scheduling, special technology, how to handle firearms on sets, and so forth. You can't qualify for certain jobs without having the right training modules. Previously, workers always had to trek down to London to attend sessions. It's a small step, but it is a product of the AFTPS's efforts. And these efforts take so much time and so much labor. It's sometimes so much effort to keep your chin up when you're constantly disappointed. Honestly, it's grueling work.

Are we at a point where production hubs are interchangeable, or do you still film in certain locations because of the distinctive topography?

There are moments when geographical considerations come into play, but if a location has a skilled labor pool and physical infrastructure in place, anything is 
possible. For example, Penny Dreadful takes place in the 1890s. In Dublin, we can find streets that pass for Victorian London. We wouldn't find those exteriors in Budapest, but the crew is so great that they would have no problem building it for us on a studio back lot. Now, could we film Penny Dreadful in Spain? No. We would have no use for the bright, sunny weather or architecture in our gothic drama. And Spain doesn't offer the same physical or human resources as Budapest. But this is an occasional exception to what has become a global market. Film and television production can take place in any of the established hubs.

Productions also base themselves in a location for the duration of filming but shuttle off for a few weeks of shooting here or there as necessary. You may set up a production office in Budapest but spend a few weeks in Croatia to get seaside exteriors, correct?

True, but people don't realize how much that adds to your budget. Even if you're only there for two weeks, it takes time to plan and prepare the logistics for moving between territories. You have to establish some sort of home base there, which requires duplicating some of your production staff and crew. Plus, you have to move your talent and key department positions. Everything comes to a halt in one location as you pick up and move to another. It causes a lot of inefficiencies and logistical nightmares. It's much easier to stay in one place.

\section{How does a production like Game of Thrones manage so many locations?}

Game of Thrones films across five or six territories simultaneously, and each location operates completely distinctly from the others. Other than key department heads, there's no need to shuffle cast and crew across multiple locations. It's a different production model rooted in this particular script: dragons film here, this kingdom films there, and so on. These characters only appear in this world, those characters only appear in that world. It's the only way to make a show like that logistically possible. As soon as there's too much crossover between narrative worlds, it won't work.

How do you get jobs?

You build a reputation. In Scotland, I'm very well known. It's easy for me to work there; there's just no work. I secure jobs through word of mouth. I've been fortunate enough to work on some high-profile productions. Producers remember your name, and they'll offer it to whomever asks for a recommendation. Or that producer will keep you on for his or her next production. I have some successful friends who always recommend me when they have the opportunity to do so-I make sure they get very nice Christmas gifts from me each year. 
It's about becoming part of a mobile production network. We're constantly in contact with one another. We know who is available when and where. It's a good time to work in Europe right now. It's a booming job market. Studios are booked eight months in advance.

If someone gave you an opportunity to work in Los Angeles, would you? How would you feel if you had the chance to move to L.A. for a stable job over the next ten years?

I could do with a little beach and a little sun. [Laughter] Honestly, I am willing to work anywhere for a few months. But any longer than that? I don't know. I actually enjoy a new job in a new place every six to nine months. I worry I would feel a bit trapped working in the same job in the same place for ten years.

You're certainly the right person with the right mindset at the right moment for the industry.

That's kind of you to say. I may be the wrong person tomorrow. You're only as good as your last job. 